\title{
Needle hygiene reduces the occurrence of post-vaccine abscesses in cattle
}

\section{A higienização de agulhas diminui a ocorrência de abscessos pós-vacinais em bovinos}

\author{
Danilo Conrado Silva ${ }^{1 *}$; Camila França de Paula Orlando Goulart ${ }^{1}$; Paulo José \\ Bastos Queiroz ${ }^{2}$; Wanessa Patrícia Rodrigues da Silva ${ }^{3}$; Lucianne Cardoso Neves²; \\ Emmanuel Arnhold ${ }^{4}$; Naida Cristina Borges ${ }^{5}$; Luiz Antônio Franco da Silva ${ }^{5}$
}

\begin{abstract}
Although vaccination is indispensable for animal production, the use of unhygienic needles can lead to post-vaccine abscesses and consequently loss of meat products and higher production costs. The aim of this study was to evaluate the efficiency of needle hygiene in the prevention of post-vaccine abscesses in cattle, estimate economic losses caused by post-vaccine abscesses, and verify whether cattle farmers sanitize the needles used in vaccination. Four groups containing 120 cattle were vaccinated against the foot-and-mouth disease. The GI, GII, and GIII groups were vaccinated using needles sanitized by different methods, while the GIV group served as control. Six months after vaccination, ultrasound exams were performed and abscesses were quantified. Subsequently, cattle were slaughtered, carcass losses due to the presence of abscesses were quantified, and economic losses were calculated. In slaughterhouses, 100 cattle farmers were interviewed on the adoption of needle hygiene for vaccines and the number of cattle they slaughtered. The numbers of abscesses diagnosed per group were as follows: GI ( $n=3,2.5 \%)$, GII $(n=5,4.2 \%)$, GIII $(n=4,3.3 \%)$, and GIV $(n=11,9.2 \%)$. The occurrence of abscesses in GI, GII, and GIII did not differ statistically from each other but was statistically lower than that observed in GIV. The economic losses due to the presence of abscesses in the carcasses varied from $\mathrm{R} \$ 0.12$ to $\mathrm{R} \$ 0.31$ per animal of the herd whose needles were sanitized or not, respectively. Only $13 \%$ of the interviewed cattle farmers carried out some method of needle hygiene for vaccination. $78.8 \%$ of the slaughtered cattle were vaccinated with needles without any sanitization method. Thus, needle hygiene for cattle vaccination decreases the occurrence of post-vaccine abscesses. This practice minimizes losses by R $\$ 0.19$ per animal due the damages caused by the removal of abscesses during the slaughter of animals. Most cattle farmers do not adopt needle hygiene for cattle vaccination.
\end{abstract}

Key words: Cattle. Economic impacts on livestock. Good livestock practices. Ultrasonography. Vaccination.

1 Drs., Programa de Pós-Graduação em Ciência Animal, Universidade Federal de Goiás, UFG, Goiânia, GO, Brasil. E-mail: dnl. conrado@gmail.com; camilafrancavet@gmail.com

2 Discentes, Programa de Pós-Graduação em Ciência Animal, UFG, Goiânia, GO, Brasil. E-mail: paulojose.vet@hotmail.com; luciannecardoso26@gmail.com

3 Discente, Programa de Residência em Área Profissional da Saúde, UFG, Goiânia, GO, Brasil. E-mail: wrodrigues.vet@gmail. com

4 Prof., Pesquisador, Programa de Pós-Graduação em Zootecnia, UFG, Goiânia, GO, Brasil. E-mail: emmanuelarnhold@yahoo. com.br

5 Profs., Pesquisadores, Programa de Pós-Graduação em Ciência Animal, UFG, Goiânia, GO, Brasil. E-mail: naidacborges@, gmail.com; prof_ufg.dmv@hotmail.com

* Author for correspondence

Received: Nov. 24, 2018 - Approved: Jan. 31, 2019 


\section{Resumo}

Embora a vacinação seja indispensável para a exploração animal, a utilização de agulhas não higienizadas pode ocasionar abscessos pós-vacinais e, consequentemente, provocar perdas de produtos cárneos e elevação do custo de produção. O objetivo do presente estudo foi avaliar a eficiência da higienização de agulhas na prevenção de abscessos pós-vacinais em bovinos, estimar as perdas econômicas ocasionadas pelos abscessos pós-vacinais e verificar se os produtores rurais higienizam as agulhas utilizadas na vacinação. Quatro grupos contendo 120 bovinos foram vacinados contra febre aftosa. Os grupos GI, GII e GIII foram vacinados utilizando-se agulhas que foram higienizadas por diferentes métodos, enquanto o grupo GIV serviu como controle. Seis meses após a vacinação, foram realizados exames ultrassonográficos e quantificados os abscessos. Posteriormente, os bovinos foram abatidos, quantificaram-se as perdas de carcaças devido à presença dos abscessos e as perdas econômicas foram calculadas. Nos frigoríficos, 100 proprietários rurais foram entrevistados sobre a adoção de higienização de agulhas para vacinas e a quantidade de bovinos que estavam abatendo. As quantidades de abscessos diagnosticados por grupo foram: GI ( $\mathrm{n}=3 ; 2,5 \%)$; GII ( $\mathrm{n}=5 ; 4,2 \%)$; GIII $(n=4 ; 3,3 \%)$; e GIV $(n=11 ; 9,2 \%)$. As ocorrências de abscessos em GI, GII e GIII não se diferiram estatisticamente, porém estas ocorrências foram estatisticamente menores que a ocorrência em GIV. As perdas econômicas decorrentes da presença de abscessos nas carcaças variaram entre R $\$ 0,12$ e $R$ \$ 0,31 por animal do rebanho cujas agulhas foram higienizadas ou não higienizadas, respectivamente. Apenas $13 \%$ dos produtores entrevistados realizavam algum método de higienização de agulhas para vacinação. $78,8 \%$ dos bovinos abatidos por estes produtores foram vacinados com agulhas sem nenhum método de higienização. Conclui-se que a higienização de agulhas para a vacinação de bovinos diminui a ocorrência de abscessos pós-vacinais. Essa prática minimiza em $\mathrm{R} \$ 0,19$ por animal os prejuízos causados pela retirada do abscesso durante o abate dos animais. A maioria dos proprietários rurais não adota a higienização de agulhas para a vacinação de bovinos.

Palavras-chave: Boas práticas pecuárias. Bovinos. Impactos econômicos na pecuária. Ultrassonografia. Vacinação.

\section{Introduction}

Brazil has the largest commercial cattle herd in the world, being the largest meat exporter of this species (RONDELLI et al., 2017). In 2017, 30.83 million cattle were slaughtered in Brazil. Goiás was the third state that most slaughtered cattle, contributing to $10.3 \%$ of the slaughter (IBGE, 2018).

Cattle farming growth is due in part to the adoption of sanitary programs, which opened the international market for exports. Among them, the Brazilian Program for Eradication of Footand-Mouth Disease (PNEFA) made it possible for Brazil to obtain the certificate of FMD-free country with vaccination in May 2018 through the massive vaccination of the herd (OIE, 2018). Although vaccination is an indispensable technology for animal exploration, the use of unhygienic needles and syringes promotes an increase in the occurrence of post-vaccine abscesses (GASPAR et al., 2015), causing losses of meat products and increases in production costs (LUSA et al., 2016). Despite the economic losses caused by post-vaccine abscesses, a significant portion of cattle farmers and researchers has still ignored this subject. Thus, it is necessary to establish control measures for post-vaccine abscesses that minimize financial losses to farmers and slaughterhouses.

The aim of this study was to evaluate the efficiency of needle hygiene in the prevention of post-vaccine abscesses in cattle, estimate the economic losses caused by post-vaccine abscesses, and verify whether cattle producers sanitize the needles used in vaccination. 


\section{Material and Methods}

\section{Division of groups and vaccination of animals}

This study started in 2012 and ended in 2018. The activities were carried out during practical classes and extension projects related to the classes of Clinics and Surgery of Large Animals given to undergraduate and graduate students of the School of Veterinary and Animal Science of the Federal University of Goiás (EVZ/ UFG). The evaluations were authorized by the Animal Ethics Committee (CEUA) of UFG with the protocols 150/2010 and 021/2016.

The evaluations were carried out on a farm of mixed exploration, located in the state of Goiás. A total of 480 male, crossbred (European $\mathrm{x}$ Zebu) cattle with an average weight of $360 \mathrm{~kg}$ and an approximate age of 24 months, free of any nodule in pre-scapular cervical subcutaneous region, were used in the evaluations. The animals were randomly distributed into four groups of 120 animals (GI, GII, GIII, and GIV).

For animals allocated in Group I(GI), hypodermic needles were previously boiled for 20 minutes before vaccination. In Group II (GII), needles were maintained in 10\% iodopovidone solution (Riodeine Tópico, Indústria Farmacêutica Rioquímica Ltda., São José do Rio Preto, São Paulo) for 10 minutes. The needles used in vaccination of animals distributed in Group III (GIII) were maintained in $0.5 \%$ sodium hypochlorite solution $(10 \%$ sodium hypochlorite, Zuppani Industrial Ltda., Goiânia, Goiás) also 10 ten minutes. In Group IV (GIV), the needles were washed only with running water and sun-dried. The latter group (GIV) was considered the control group. In all groups, needles were stored in pre-boiled glass bottles with a wide mouth and a lid. In all the hygiene methods used, needles were placed in containers 30 minutes before starting the vaccination.

In groups GI, GII, and GIII, needles were removed from the flasks with anatomical tweezers and manually coupled to a pistol syringe. In group
GIV, the removal of needles from the flask was performed manually, without concern for keeping it closed during the vaccination process. In addition, the needles were replaced in GIV only when damaged. In the other groups, the replacement was always performed after the vaccination of ten animals. A single pistol-type syringe suitable for administration of vaccines in cattle was used, being duly sanitized before the vaccination of each group. All animals received a dose of $5 \mathrm{~mL}$ of foot-andmouth disease vaccine (Bovicel Vallée S/A, Montes Claros, Minas Gerais), subcutaneously applied on the right side of the neck, in the pre-scapular region, using a $10 \times 15 \mathrm{~mm}$ hypodermic needle.

\section{Identification of abscesses and ultrasonography}

Six months after vaccination, animals were examined and those with abscesses in the vaccination region underwent an ultrasonographic evaluation to confirm the presence of abscesses. Ultrasonography was carried out with animals contained in a standing stock, without sedation. Before performing the ultrasonographic exam, a trichotomy was performed with a shearing machine in the region to be examined. The images were obtained in B mode using a LOGIQ $\mathrm{E}^{\circledR}$ ultrasound (GE Healthcare ${ }^{\circledR}$, Fairfield, Merseyside) with a multi-frequency linear transducer at the 8.5 $\mathrm{MHz}$ frequency and topical application of exam transmission gel. Subsequently, all the animals were sent to slaughter in a slaughterhouse under Federal Inspection, following the recommended procedures at each unit.

\section{Weighing of discarded tissues and microbiological evaluation}

After the skinning process and previous cleaning of carcasses in the slaughterhouses, the abscesses and adjacent tissues were removed and the discarded tissue was individually weighed. These values were recorded and used to calculate the economic losses 
due to abscesses. This calculation was based on the arroba value paid to the farmer in Goiânia, GO, Brazil, and the dollar exchange rate, both on June 1, 2018. The number of animals slaughtered in Brazil in 2017 was used for estimating economic losses (Table 1).

After removing the lesions, samples of abscesses were collected for microbiological analysis.
Samples were obtained by puncture of the removed subcutaneous abscesses using $10 \mathrm{~mL}$ sterile syringes and $40 \times 12 \mathrm{~mm}$ hypodermic needles. Aliquots of $1 \mathrm{~mL}$ were obtained from each puncture, being transferred to sterile tubes previously identified containing $2 \mathrm{~mL}$ of Ringer-PRAS solution. Samples were conditioned in an isothermal box containing recyclable ice.

Table 1. Values used for the evaluation of economic losses due to post-vaccine abscesses in cattle.

\begin{tabular}{cccc}
\hline Description & Value & Data & Source \\
\hline Price of arroba paid to the farmer (R\$) & 126.00 & $06 / 01 / 2018$ & (SCOT, 2018) \\
US dollar exchange rate (US\$) & 3.74 & $06 / 01 / 2018$ & (BCB, 2018) \\
Total of animals slaughtered in Brazil in 2017 & $30,830,000.00$ & - & (IBGE, 2018) \\
\hline
\end{tabular}

Samples were sent to the Laboratory of Bacteriology of EVZ/UFG. In the laboratory, aliquots of each sample were distributed in 5\% sheep blood agar and MacConkey agar and incubated in an incubator at $37{ }^{\circ} \mathrm{C}$ in aerobiosis for 48 hours. After the growth of pure colonies, the identification was carried out through the study of growth time using morpho-tinctorial characteristics of bacteria and colonies, Gram technique, and biochemical tests. The respiratory test was performed by inoculating the bacterial samples into the culture media, which were incubated at $37^{\circ} \mathrm{C}$ for 48 hours in appropriate jars, under anaerobic conditions produced by sachets. The Bergey's Manual of Systematic Bacteriology (BERGEY; HOLT, 2000) was used to assist in the identification of bacterial strains.

\section{Questionnaire for farmers}

At this stage, questionnaires were applied to 100 farmers in the state of Goiás. Interviews were conducted at the same slaughterhouses where the slaughtered animals were evaluated for the presence of abscesses. As farmers arrived to accompany the slaughter of their animals, they were invited to participate in the survey. The questionnaires contained questions related to the use or not of some hygiene method of needles and syringes used to vaccinate the cattle against foot-and-mouth disease. In addition, the number of cattle slaughtered during the survey was questioned.

\section{Statistical analysis}

The frequencies of occurrence of abscesses were compared between groups GI, GII, GIII, and GIV. The total frequency of abscesses was also compared in the groups in which the animals were vaccinated with sanitized needles (GI, GII, and GIII) in relation to group GIV. For the statistical evaluation of the data, the Chi-square test $\left(\chi^{2}\right)$ was used for the first comparison and Fisher's exact test for the second comparison. The value of $\mathrm{p}<0.05$ was considered statistically significant. The information obtained through the application of questionnaires to cattle farmers was presented through descriptive statistics. The statistical software R (R CORE TEAM, 2018) was used for the data analysis. 


\section{Results}

Among the 480 animals vaccinated and monitored until the slaughtering time, $23(4.8 \%)$ presented post-vaccine abscesses. The ultrasound evaluation showed that most abscesses $(n=20$;
$87 \%$ ) were present in the subcutaneous tissue (Figure 1A). However, the presence of abscesses was also observed in the muscle tissue $(\mathrm{n}=3 ; 13 \%)$ (Figure 1B).

Figure 1. Ultrasonography in longitudinal section of a post-vaccine abscess in the cervical pre-scapular region of adult cattle. (A) Abscess located to the subcutaneous tissue. (B) Abscess located in the muscle tissue. Both abscesses present heterogeneous contents with hyperechoic points and are delimited by a hyperechoic capsule $(\mathrm{C}) . \mathrm{Cr}$ - cranial; Sc - subcutaneous; M - muscle.
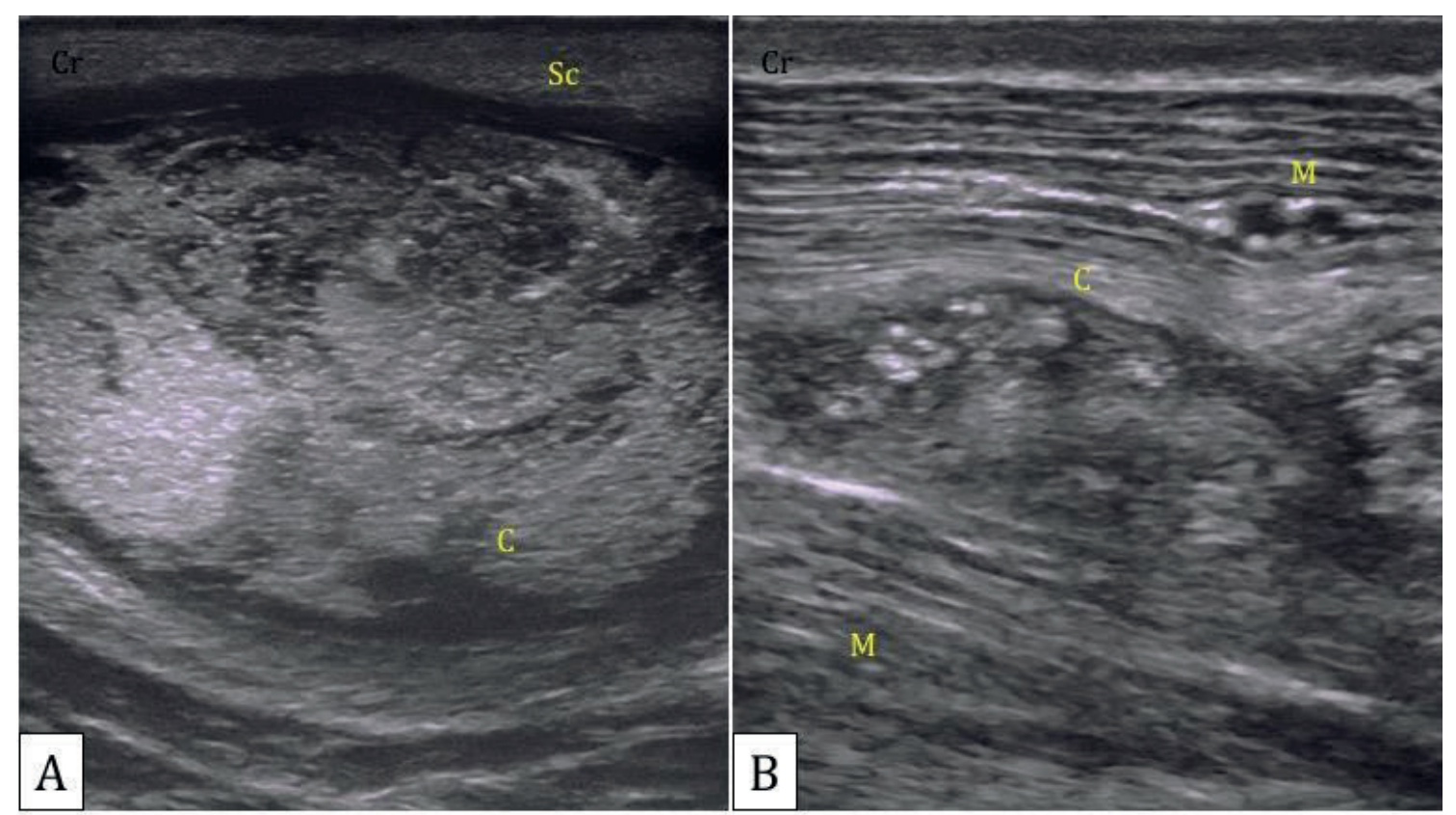

Group GIV had 11 animals $(9.2 \%)$ with postvaccine abscesses, representing $42.8 \%$ of the animals with abscesses. The occurrence of abscesses in GIV was significantly higher $(\mathrm{p}=0.01)$ when compared to the other groups. No statistical difference was observed among the GI, GII, and GIII groups ( $p$ $=0.88$ ) regarding the occurrence of abscesses (Table 2). Table 2 shows the bacteria identified in the microbiological evaluation of abscesses after animal slaughtering. 
Table 2. Cases of post-vaccine abscesses and types of bacteria present in the abscesses of 480 cattle submitted to vaccination against foot-and-mouth disease according to the type of needles and hygiene method used (GI, GII, GIII or GIV).

\begin{tabular}{|c|c|c|c|}
\hline Group & Cattle with abscesses & Number of animals & Bacteria found in the microbiological evaluation \\
\hline GI & $3(2.50 \%)^{\mathrm{a}}$ & 120 & $\begin{array}{l}\text { Staphylococcus spp., Arcanobacterium spp., } \\
\text { Pseudomonas spp., and Micrococcus spp. }\end{array}$ \\
\hline GII & $5(4.2 \%)^{\mathrm{a}}$ & 120 & $\begin{array}{l}\text { Staphylococcus spp., Arcanobacterium spp., } \\
\text { Micrococcus spp., and Pseudomonas spp. }\end{array}$ \\
\hline GIII & $4(3.3 \%)^{\mathrm{a}}$ & 120 & $\begin{array}{l}\text { Staphylococcus spp., Micrococcus sp., } \\
\text { and Pasteurella sp. }\end{array}$ \\
\hline GIV & $11(9.2 \%)^{b}$ & 120 & $\begin{array}{c}\text { Staphylococcus spp., Arcanobacterium spp., Micrococcus } \\
\text { spp., and Arcanobacterium spp. }\end{array}$ \\
\hline
\end{tabular}

GI - hypodermic needles pre-boiled for 20 minutes; GII - needles maintained in 10\% iodopovidone solution for 10 minutes; GIII - needles maintained in $0.5 \%$ sodium hypochlorite solution for 10 minutes; GIV - needles washed only under running water and sun-dried (control group). ${ }^{\mathrm{a}, \mathrm{b}}$ Values followed by different letters differ statistically from each other by the chi-square test $(p<0.05)$.

Table 3 shows the average and total weights $(\mathrm{kg})$ of tissues removed due to the presence of postvaccine abscesses. The groups that used needle hygiene methods (GI, GII, and GIII) showed that among the 360 vaccinated cattle, $12(3.3 \%)$ had post-vaccine abscesses, while in GIV, among the 120 vaccinated animals, 11 (9.2\%) had abscesses (Table 4). Needle hygiene (GI, GII, and GIII) promoted a lower occurrence of abscesses $(p=0.013)$ in relation to non-sanitized needles (GIV). The weight of the total removed tissue and the economic losses associated with the presence of post-vaccine abscesses are shown in Table 4. At the end of the economic evaluation, losses due to the presence of abscesses in the carcasses varied from $\mathrm{R} \$ 0.12$ to $\mathrm{R} \$ 0.31$ per animal of the herd whose needles were sanitized and not sanitized, respectively. This shows an average saving of $\mathrm{R} \$ 0.19$ per animal that was vaccinated with sanitized needles.

Table 3. Average and total weight in kilograms $(\mathrm{kg})$ of tissue removed due to the presence of post-vaccine abscesses six months after vaccination against foot-and-mouth disease using needles submitted to different hygiene methods on a rural property in the state of Goiás.

\begin{tabular}{ccc}
\hline Group & Average weight $(\mathrm{kg})$ & Total weight of removed tissues $(\mathrm{kg})$ \\
\hline I & 0.448 & 1.345 \\
II & 0.389 & 1.945 \\
III & 0.458 & 1.833 \\
IV & 0.436 & 4.802 \\
Total & 0.432 & 9.925 \\
\hline
\end{tabular}


Table 4. Cases of post-vaccine abscess, removed portion weights, and mean economic loss per animal and total in cattle vaccinated against foot-and-mouth disease using sanitized (GI, GII, and GIII) and non-sanitized needles (IV).

\begin{tabular}{lccccc}
\hline Group & $\begin{array}{c}\text { Cattle with } \\
\text { abscesses }\end{array}$ & $\begin{array}{c}\text { Total weight of } \\
\text { removed tissue } \\
(\mathrm{kg})\end{array}$ & $\begin{array}{c}\text { Total economic } \\
\text { loss in Reais } \\
(\mathrm{R} \$)^{*}\end{array}$ & $\begin{array}{c}\text { Total economic } \\
\text { loss in dollars } \\
(\text { US\$)** }\end{array}$ & $\begin{array}{c}\text { Average } \\
\text { economic loss } \\
\text { per herd (R\$) }\end{array}$ \\
\hline Sanitized & $12 / 360(3.33 \%)^{\mathrm{a}}$ & 5.123 & 43.03 & 11.50 & 0.12 \\
Non-sanitized & $11 / 120(9.17 \%)^{\mathrm{b}}$ & 4.802 & 36.62 & 9.79 & 0.31 \\
Total & $23 / 480$ & 9.92 & 79.65 & 21.29 & 0.17 \\
\hline
\end{tabular}

a,b Values followed by different letters differ statistically from each other by the Fisher's exact test $(p<0.05)$. ${ }^{*}$ Considering the arroba value of R\$126.00, referring to the spot price in the region of Goiânia, GO, Brazil, in June 2018. **Considering the value of the dollar (US\$) of R\$ 3.74 on 06/01/2018.

Among the 100 cattle farmers that were questioned about needle hygiene used in the vaccination, only 13 (13\%) performed some hygiene method. The interviewed cattle farmers slaughtered 16,000 animals during the survey, of which 3,400 $(21.2 \%)$ were vaccinated with sanitized needles and $12,600(78.8 \%)$ were vaccinated without any hygiene method.

\section{Discussion}

The results found in this study show the importance of adopting procedures to sanitize needles used in vaccination, as well as their replacement after vaccinating some animals. This finding was demonstrated when comparing it with the group in which no hygiene method was used. In an attempt to maintain consistency with the routine of numerous rural properties, in addition to not sanitizing the needles, their replacement only occurred when they were damaged. Although the methodology used in the study does not allow differentiating whether hygiene or needle replacement was the most important factor for reducing abscesses, the adoption of these measures is a viable alternative to reduce this complication. In addition, other authors (SOUZA et al., 2009; GASPAR et al., 2015) recommended the hygiene of tools used in the vaccination, but they did not present quantitative data proving its efficiency in the reduction of post-vaccine abscesses.
Arguing about the set of measures adopted here and aimed at improving the efficiency of immunization, also called good vaccination practices, it is possible to relate a number of advantages attributed to this protocol. Among the main benefits of good vaccination practices are the lower vaccine losses, minimization of the frequency of equipment damage, including needle and syringe malfunctions, reduced risk of work-related accidents, and reduced occurrence of vaccine abscesses (GASPAR et al., 2015). Although there were no reports of work-related accidents in this study, the implementation of preventive measures and ergonomic techniques should be considered during vaccination. However, when ignoring good vaccination practices such as lack of equipment hygiene, the increase in the prevalence of postvaccine abscesses was significant. These findings have greater importance when considering the damages to leather and losses resulting from carcass cleaning. Similar data were reported by other authors (FRANÇA, 2012; MARQUES et al., 2018).

The presence of abscesses in all the evaluated groups can be attributed to several factors. Particularly, in animals in which needles were sanitized prior to vaccination, the complication may have been due in part on dirtiness sheltered in hairs and/or skin and transported by needles during the vaccination. Thus, considering that an abscess is a circumscribed collection of pus formed in different 
tissues, post-vaccine tumors would be a response to the development of pyogenic bacteria from the external environment. In such circumstances, although the evolution of this complication predisposes to bacteremia, the formation of a fibrous tissue capsule isolates neighboring tissues and minimizes sepsis setting. Bacterial contamination is the main cause of abscess formation in domestic animals, which can be produced by irritant agents of a chemical or mechanical nature and later by bacterial development (KUMAR et al., 2016). The mineral oil present in foot-and-mouth disease vaccines and in some drugs has also been held responsible for the formation of abscesses (MORO et al., 2001), justifying in part the appearance of abscesses in animals belonging to the groups that received previous hygiene of the equipment. Nevertheless, hygiene significantly reduced the appearance of these tumors in vaccinated animals.

The presence of Staphylococcus spp. isolated from abscesses of animals from all groups was a predictable result. This microorganism is found colonizing the natural flora, mainly in the skin, but can become pathogenic under conditions such as the breakage of the cutaneous blade. Trauma that compromises the integrity of the cutaneous barrier is the main cause of change in the behavior of this microorganism, making it the most frequent etiologic agent in cutaneous infections. Therefore, we can infer that during vaccination against the foot-andmouth disease, in addition to equipment hygiene, the antisepsis at the place reserved for immunization should also be performed. Other authors found similar results on the colonization of Staphylococcus spp. (SANTOS et al., 2007; TORTORA et al., 2005).

Economic losses due to post-vaccine abscesses close to half a kilogram estimated in this study may individually not be an expressive loss. However, the values can achieve substantial economic losses when considering the total cattle slaughtered annually in Brazil. Similar losses were reported by other researchers in a study conducted in the state of Goiás with 2,662 cattle slaughtered in slaughterhouses under inspection. The average weight related to the muscle tissue removal from the abscess region was $0.213 \mathrm{~kg}$ in the total abscessed animals. The authors estimated an average loss that varied from $\mathrm{R} \$ 0.11$ to R\$ 1.39 per animal (FRANÇA FILHO et al., 2006).

Considering that the conducted interviews confirmed that 12,600 cattle were vaccinated without any care with the hygiene of the equipment and that individual losses in these cases are R $\$ 0.19$ more per animal, it is estimated a total loss of $\mathrm{R} \$$ 2,394.00. Extrapolating it to a universe of 30.83 million cattle slaughtered in Brazil only in 2017 (IBGE, 2018), it is clear its importance in the face of possible losses imposed on cattle farmers and meat industry. According to the estimates obtained from the interviews, considering $78.8 \%$ of vaccinated animals without needle hygiene and extrapolating this data to the total number of animals slaughtered in Brazil in 2017, we estimate an economic loss of $\mathrm{R} \$ 4,615,867.00$ in this period, which is due only to the lack of good practices with hygiene of needles for vaccine.

In the United States, losses due to carcass lesions were estimated at US\$ 55 million in 1991 in a study carried out in slaughterhouses, distributors, restaurants, and packers (SMITH et al., 1992). In Brazil, Moro and Junqueira (1999) estimated an annual loss of US\$ 11.3 million only when inspecting the slaughtering line of slaughterhouses. These authors carried out a study on the occurrence of injuries during an inspection in the slaughtering line in eight slaughterhouses of different states and observed the occurrence of $68.6 \%$ of animals with lesions, requiring the removal of $1,112.79 \mathrm{~kg}$ of meat from a total of 4,000 examined animals, resulting in an average of $0.278 \mathrm{~kg}$ of meat removed per animal. More recently, Cardoso (2015) described a mean loss of $0.108 \mathrm{~kg}$ per carcass in a study carried out in the Northeast region and state of Rio Grande do Sul, Brazil. Considering only injuries resulting from vaccines and/or drugs, this value represented a loss of approximately R $\$ 1.06$ per slaughtered animal. Although these values are, on average, lower when 
compared to those found in our study, we cannot ignore that the losses are huge. Therefore, when summing the losses resulting from post-vaccine abscesses to other losses resulting from death due to innumerable diseases and inherent to the management, the amount, besides being considerable, may even make the business unfeasible.

An ultrasound exam was of great importance in this study, as it revealed the extent of the lesion and facilitated the drainage of abscesses, which is an alternative treatment before slaughter that minimizes, in part, the losses to farmers, companies, and State. The fact that some abscesses invade the animal's musculature and not only the subcutaneous tissue was another finding evidenced by the ultrasound exam. In these circumstances and if abscess location compromises important commercial cuts for the meat industry, the damages can be intensified, justifying the use of the imaging exam. Ultrasound in cattle was first used in the evaluation of the reproductive tract in the 70 s. The use of this method as an ancillary exam in clinical or surgical evaluation of cattle is relatively recent, but can be used to guide the veterinarian to perform safer drainage of abdominal abscesses, besides being able to control its efficiency (RIZZO et al., 2014). In the researched literature, no studies were found using ultrasonography in the diagnosis and treatment of post-vaccine abscesses in cattle. This finding reinforces the relevance of the examination performed in the animals of this study.

At the end of this study, the authors reflect not only on the losses caused by post-vaccine abscesses but also on the pain triggered by these tumors. Therefore, it is permissible that such complications compromise the welfare and, consequently, inhibit the expression of productive and reproductive potential, causing considerable economic losses to cattle farming. The discomfort interferes negatively with feed conversion since the animal organism does not take full advantage of nutrients for muscular growth. These losses are related to the energy consumed in the immune defense and to the contaminated muscle tissue, which is removed during the carcass cleaning. Considering this scenario, it is necessary to include in the routine of rural properties some method of sterilizing needles and syringes used in vaccination in order to reduce the occurrence of post-vaccine abscesses in cattle, contribute to animal welfare and, consequently, minimize the economic losses caused by the disease. However, a small number of researchers has explored this subject (ASSIS et al., 2011; FRANÇA FILHO et al., 2006; LUSA et al., 2016).

\section{Conclusions}

Needle hygiene for cattle vaccination reduces the occurrence of post-vaccine abscesses. Needle hygiene for cattle vaccination minimizes at $\mathrm{R} \$ 0.19$ per animal the losses caused by abscess removal during animal slaughter. Most farmers do not adopt needle hygiene for cattle vaccination.

\section{References}

ASSIS, D.; REZENDE-LAGO, N. C. M.; MARCHI, P. G. F. de; D'AMATO, C. C. Direct losses due abscesses and bruised in beef carcasses. Revista Portuguesa de Ciências Veterinárias, Lisboa, v. 106, n. 577-580, p. 4751, 2011.

BANCO CENTRAL DO BRASIL - BCB. Câmbio. [Sl. s,n.], 2018. Disponível em: https://www.bcb. gov.br/. Acesso em: 1 jun. 2018.

BERGEY, D. H.; HOLT, J. G. Bergey's manual of determinative bacteriology. $9^{\text {th }}$ ed. Philadelphia: Lippincott Willians \& Wilkins, 2000. 787 p.

CARDOSO, J. C. Perdas econômicas devido a lesões por aplicação medicamentosas elou vacinais em carcaças de bovinos abatidos na região nordeste do Rio Grande do Sul. 2015. Monografia (Trabalho de Conclusão do Curso de Especialização em Produção, Tecnologia e Higiene de Produtos de Origem Animal) - Universidade Federal do Rio Grande do Sul, Porto Alegre.

FRANÇA FILHO, A. T.; ALVES, G. G.; MESQUITA, A. J.; CHIQUETTO, C. E.; BUENO, C. P.; OLIVEIRA, A. S. C. Perdas econômicas por abcessos vacinais e/ou medicamentosos em carcaças de bovinos abatidos no estado de Goiás. Ciência Animal Brasileira, Goiânia, v. 7, n. 1, p. 93-96, 2006. 
FRANÇA, R. P. Avaliação das boas práticas de vacinação como forma de minimizar a formação de abscessos vacinais em bovinos vacinados contra febre aftosa. 2012. Monografia (Trabalho de Conclusão do Curso de Graduação em Medicina Veterinária) - Universidade de Brasília, Brasília.

GASPAR, E. B.; MINHO, A. P.; SANTOS, L. R. Manual de boas práticas de vacinação e imunização de bovinos. Bagé: EMBRAPA, 2015. 10 p. (Circular técnica, 47). Disponível em: https://ainfo.cnptia.embrapa. br/digital/ bitstream/item/128128/1/CiT-47-15-online.pdf. Acesso em: 29 set. 2018 .

INSTITUTO BRASILEIRO DE GEOGRAFIA E ESTATÍSTICA - IBGE. Em 2017, cresce abate de bovinos e suínos, mas cai o de frangos. Rio de Janeiro: IBGE, 2018. Disponível em: https://agenciadenoticias. ibge. gov.br/ agencia-sala-de-imprensa/2013-agenciade-noticias/releases/20523-em-2017-cresce-abate-debovinos-e-suinos-mas-cai-o-de-frangos. Acesso em: 29 set. 2018.

KUMAR, V.; ABBAS, A. K.; ASTER, J. C. Patologia: bases patológicas das doenças. 9. ed. Rio de Janeiro: Elsevier, 2016. 1422 p.

LUSA, A. C. G.; REZENDE, M. P. G.; SOUZA, J. C.; MALHADO, C. M. Reflexos econômicos de perdas quantitativas por abcessos vacinais em carcaças de bovinos abatidos no estado da Bahia, Brasil. Boletim de Indústria Animal, Nova Odessa, v. 73, n. 2, p. 165-170, 2016. DOI: 10.17523/bia.v73n2p165

MARQUES, K. A.; PEDREIRA, M. S.; OLIVEIRA, K. P.; PITTA, B. S. L.; ARAUJO, A. C.; CARDOSO, P. H. S.; SANTOS, I. D.; SOUSA, G. S. Peso e tipo de abscesso em bovinos de corte submetidos à vacina da febre aftosa no sudoeste da Bahia. In: REUNIÃO ANUAL DA SOCIEDADE BRASILEIRA DE ZOOTECNIA E CONGRESSO BRASILEIRO DE ZOOTECNIA, 55., 28., 2018, Goiânia. Anais... Goiânia: Sociedade Brasileira de Zootecnia e Associação Brasileira de Zootecnistas, 2018. p. 1-4.

MORO, E.; JUNQUEIRA, J. O. B. Levantamento da incidência de reações vacinais e/ou medicamentosas em carcaças de bovinos ao abate em frigoríficos no Brasil. $A$ Hora Veterinária, Porto Alegre, v. 112, p. 74-77, 1999.

MORO, E.; JUNQUEIRA, J. O.; UMEHARA, O. Levantamento da incidência de reações vacinais e/ou medicamentosas em carcaças de bovinos na desossa em frigoríficos no Brasil. A Hora Veterinária, Porto Alegre, v. 123, p. 55-57, 2001.

ORGANIZAÇÃO MUNDIAL DE SANIDADE ANIMAL - OIE. List of FMD free member countries according to Resolution No. $22\left(86^{\text {th }}\right.$ General Session of World Assembly, May 2018). Paris: OIE, 2018. Available at: http:/www.oie.int/fileadmin/Home/eng/Animal Health_in_the_World/docs/pdf/ Resolutions/2018/A22_ RESO_2018_FMD.pdf. Accessed at: 29 sept. 2018.

R CORE TEAM - R: a language and environment for statistical computing. Vienna: R Foundation for Statistical Computing, 2018. Available at: https://www.R-project. org/. Accessed at: 23 sept. 2018.

RIZZO, H.; ROSSI, R. S.; SOUZA, M. J. E. B. de; RAMALHO, N. P.; LEONARDO, B.; RIBEIRO, B. L. M.; GREGORY, L. Uso do ultrassom em bovinos com enfermidades intestinais e dos anexos do tubo digestivo. Ciência Animal, Fortaleza, v. 24, n. 1, p. 46-61, 2014.

RONDELLI, L. A. S.; SILVA, G. S.; BEZERRA, K. S.; RONDELLI, A. L. H; LIMA, S. R.; FURLAN, F. H.; PESCADOR, C. A.; COLODEL, E. M. Doenças de bovinos em Mato Grosso diagnosticadas no Laboratório de Patologia Veterinária da UFMT (2005-2014). Pesquisa Veterinária Brasileira, Rio de Janeiro, v. 37, n. 5, p. 432440, 2017. DOI: 10.1590/s0100-736x2017000500002

SANTOS, A. L.; SANTOS, D. O.; FREITAS, C. C.; FERREIRA, B. L. A.; AFONSO, I. F.; RODRIGUES, C. R.; CASTRO, H. C. Staphylococcus aureus: visiting a strain of clinical importance. Jornal Brasileiro de Patologia e Medicina Laboratorial, Rio de Janeiro, v. 43, n. 6, p. 413-423, 2007. DOI: 10.1590/S167624442007000600005

SCOT CONSULTORIA - SCOT. Mercado Físico 01/06/2018. Bebedouro: SCOT, 2018. Disponível em: https://www. scotconsultoria.com.br/. Acesso em: 1 jun. 2018.

SMITH, G. C.; SAVEL, J. W.; CLAYTON, R. P.; FIELD, T. G.; GRIFFIN, D. E.; HALE, D. S.; MILLER, H. F.; MONTGOMERY, T. H.; MORGAN, J. B.; TATUM, J. D.; WISE, J. W.; WILKES, D. L.; LAMBERT, C. D. Improve the consistency and competitiveness of beef. The Final Report of the National Beef Quality Audit 1991. Englewood: National Cattlemen's Association, 1992.85 p.

SOUZA, V. F.; SOARES, C. O.; FERREIRA, S. F. Vacinação, a importância das boas práticas $e$ a prevenção de doenças de interesse em bovinocultura. Campo Grande: EMBRAPA, 2009. 15 p. (Comunicado técnico, 122). Disponível em: https://ainfo.cnptia. embrapa.br/digital/bitstream/item/175356/1/Vacinacaoa-importancia-das-boas-praticas-e-a-prevencao.pdf. Acesso em: 29 set. 2018.

TORTORA, G. J.; FUNKE, B. R.; CASE, C. L. Microbiologia. 8. ed. Porto Alegre: Artmed, 2005. 894 p. 